\title{
AGRONOMIC PERFORMANCE OF CASSAVA GENOTYPES FROM THE IN VITRO SHOOT TIP CULTURE SUBMITTED TO CLONAL CLEANING
}

\author{
DESEMPENHO AGRONÔMICO DE GENÓTIPOS DE MANDIOCA PROVENIENTES \\ DO CULTIVO IN VITRO DE ÁPICES CAULINARES SUBMETIDOS À LIMPEZA \\ CLONAL
}

\author{
Mariane de Jesus da Silva de CARVALHO ${ }^{1}$; Eder Jorge de OLIVEIRA ${ }^{2}$; \\ Antônio da Silva SOUZA ${ }^{2}$; Luziane Brandão ALVES ${ }^{3}$; Marcela Tonini VENTURINI ${ }^{1}$ \\ 1. Doutoranda do Programa de Pós Graduação em Ciências Agrárias, Universidade Federal do Recôncavo da Bahia, Cruz das Almas, \\ BA, Brazil; 2. Pesquisador da Embrapa Mandioca e Fruticultura, Cruz das Almas, BA, Brazil. eder.oliveira@embrapa.br; 3. Estudante \\ de Biologia, Universidade Federal do Recôncavo da Bahia, Cruz das Almas, BA, Brazil.
}

\begin{abstract}
This study aimed to evaluate the agronomic performance of cassava genotypes from the in vitro shoot tip culture to eliminate the cassava frogskin disease for several root and aerial part characteristics. Cassava plants from accessions BGM0315, BGM0464 and BGM0841 infected with cassava frogskin disease were grown in a greenhouse after clonal cleaning. Cuttings from the three accessions were subjected to tetracycline concentrations $(0,5,10$ and $15 \mathrm{mg}$ $\left.\mathrm{L}^{-1}\right)$ for three minutes, and then maintained in an acclimatized chamber $\left(35 \pm 1{ }^{\circ} \mathrm{C}\right.$ and 16 hour photoperiod). Shoots were disinfected for excising shoot tips $(0.2 \mathrm{~mm}$ and $0.4 \mathrm{~mm})$ and inoculated in a culture medium containing the same concentrations of tetracycline used in the cuttings. After 60 days of cultivation, the explants were transferred to medium without antibiotic, 30 days later they were acclimatized for a period of 70 days for subsequent planting in the field. Seven months after planting, agronomical evaluation was held for root and aerial part characteristics. No influence of isolated shoot tip size was noticed on agronomic characteristics, while the addition of tetracycline in the culture medium, specifically at the concentrations of $5 \mathrm{mg} \mathrm{L}^{-1}$ and $15 \mathrm{mg} \mathrm{L}^{-1}$, was favorable to the development of the root system of plants in the field. The results revealed that the agronomic performance of cassava plants derived from in vitro cultivation are higher for the production of basic propagation material for the following production cycles, as well as root production for commercial use with subsequent generation of income.
\end{abstract}

KEYWORDS: Manihot esculent Crantz. Tissue culture. Phytosanitary quality. Root yield.

\section{INTRODUCTION}

Cassava (Manihot esculenta Crantz) is considered one of the main carbohydrate sources and, therefore, has great importance worldwide as a staple food for millions of people in Latin America and Africa (ALVAREZ et al., 2007). The high cassava production (over 23 million tons) places Brazil in a prominent position in the world rankings, coming in fourth among the top five producers (FAO, 2014). Despite its important economic and social expression, various abiotic and biotic stresses may compromise cassava productivity. Among those that directly affect cassava root production, root rot stands out as it is caused by Phytophthora $s p$ and Fusarium $s p$ fungus and the disease known as cassava frogskin disease (CALVERT; THRESH, 2002; MATTOS et al., 2002; ALVAREZ et al., 2009; CARVAJAL-YEPES et al., 2014). The etiology of the cassava frogskin disease has not been fully defined, but generally has been associated with phytoplasma (ALVAREZ et al., 2009) and viral complexes (CARVAJAL-YEPES et al., 2014).

Cassava frogskin was reported to cause up to $90 \%$ productivity losses in cassava in Colombia
(ALVAREZ et al., 2007). Currently, the main control measures are preventive, mostly related to the eradication of infected plants, use of healthy cuttings for planting and sanitization of cutting tools used in cultivation (CALVERT; THRESH, 2002; ALVAREZ et al., 2014). Once cassava is infected, effective strategies must be adopted to eliminate the disease so that the material can be re-incorporated into the crop production system. Currently, meristem cultivation has been touted as an effective technique for eliminating viruses and phytoplasmas in many species (SINGH et al., 2007; FAYEK et al., 2009; BANERJEE et al., 2010; MWANGANGI et al., 2014).

As infected material has been cleaned using in vitro culture, it is essential to evaluate the agronomic performance of plants generated through this biotechnology strategy. Some work has emphasized good agronomic performance in different species after in vitro culture (SANDHU et al., 2009; CHAVAN-PATIL et al., 2010; OZTURK et al., 2012; ALAM et al., 2013; ŻEBROWSKA et al., 2015; DIENGNGAN et al., 2016). However, there is still criticism and little information available on the cost-effectiveness and performance of 
cassava plants from tissue culture under field conditions (MSOGOYA; VILJOEN, 2006). In addition, clonal propagation for other species has led to speculation that changes in agronomic value can be observed in seedlings derived from tissue culture (ŻEBROWSKA et al., 2015).

Considering the urgent need to clean cassava cultivars infected with viruses and phytoplasma, it is of paramount importance to assess the field performance of in vitro propagated plants to verify their genetic fidelity or productive superiority to conventionally propagated plants. The objective of this study was to evaluate the agronomic performance of cassava genotypes from in vitro shoot tip cultivation to eliminate cassava frogskin disease as well as root and shoot characteristics.

\section{MATERIAL AND METHODS}

\section{Plant material}

Field experiments were conducted in Cruz das Almas, BA, Brazil (1240'19'S, 3906'22'W, $226 \mathrm{~m}$ altitude) under Aw climate (Köppen) in a yellow oxisol with sandy clay texture. Cassava plant accessions "CM-425/7" (BGM0315), "Sabará" (BGM0464) and "Sauma" (BGM0841) from the Cassava Germplasm Bank were used as the plant material and were grown in a greenhouse after clonal cleaning of cassava frogskin disease.

\section{Growing conditions}

The plants used in this study were produced from shoot tips that went through clonal cleaning. Initially, the cuttings from BGM0315, BGM0464 and BGM0841 cassava accessions were demonstrably infected with cassava frogskin disease, based on visual inspection of the symptoms of the disease, and were immersed in water containers and tetracycline concentrations of $0 ; 5$, 10 and $15 \mathrm{mg} \mathrm{L}^{-1}$ for 3 minutes, then transferred to polyethylene pots containing plant substrate and maintained at a constant temperature of $35^{\circ} \mathrm{C} \pm 1$ ${ }^{\circ} \mathrm{C}$. The photoperiod used in the climate chamber was 16 hours for a period of 3-4 weeks.

Emerged shoots from cuttings measuring approximately $2 \mathrm{~cm}$ in length were collected and then subjected to a disinfestation process and laminar flow chamber, during which they were immersed in $50 \%$ ethanol for 3 minutes and $0.25 \%$ sodium hypochlorite for 3 minutes, followed by triple rinsing in distilled water and autoclaving.

After this process, $0.2-\mathrm{mm}$ and $0.4-\mathrm{mm}$ shoot tips were removed. The explants were transferred to cassava establishment medium containing salt (MURASHIGE; SKOOG, 1962) supplemented with $0.02 \mathrm{mg} \mathrm{L}^{-1}$ naphthaleneacetic acid, $0.04 \mathrm{mg} \mathrm{L}^{-1}$ of benzylaminopurine, $0.05 \mathrm{mg} \mathrm{L}^{-1}$ of gibberellic acid and $20 \mathrm{~g} \mathrm{~L}^{-1}$ sucrose; solidified with $2.4 \mathrm{~g} \mathrm{~L}^{-1}$ Phytagel $^{\circledR ;} \mathrm{pH}$ adjusted to 5.8; and supplemented with $0,5,10$ and $15 \mathrm{mg} \mathrm{L}^{-1}$ tetracycline antibiotic. After being grown at each concentration of tetracycline, the apexes were placed in a growth chamber under temperature of 27 ${ }^{\circ} \mathrm{C} \pm 1{ }^{\circ} \mathrm{C}$ with a 16 -hour photoperiod and photon flux density of $30 \mu \mathrm{mol} \mathrm{m} \mathrm{m}^{-2} \mathrm{~s}^{-1}$ for 45 days (establishment phase). In this experiment, a completely randomized, triple-factorial $(3 \times 2 \times 4)$ design were used (three accessions, two shoot tip sizes and four tetracycline concentrations) totaling 24 treatments with 20 repetitions per treatment.

After 60 days of in vitro culture, in a laminar flow chamber, calluses were removed from the shoot tips and explants were transferred to test tubes containing multiplication medium MS 001, supplemented with $0.01 \mathrm{mg} \mathrm{L}^{-1}$ naphthaleneacetic acid, benzylaminopurine and gibberellic acid, $20 \mathrm{~g}$ $\mathrm{L}^{-1}$ sucrose and $2.4 \mathrm{~g} \mathrm{~L}^{-1}$ Phytagel $^{\circledR}$ without tetracycline. The $\mathrm{pH}$ of the medium and the cultivation conditions were the same as during the establishment phase. After 30 days, the plants were acclimatized, transferred to plastic bags containing a mixture of vegetable substrate, topsoil and coir $(1: 1: 1)$.

\section{Planting in the field and further agronomic characterization}

After 70 days in the greenhouse, the plants were taken to the field. Planting was carried out in two randomized blocks, with each experimental plot consisting of four to five plants, depending on the number of surviving plants in each treatment. The spacing used was $0.90 \times 0.80 \mathrm{~m}$ between rows and plants, respectively.

After seven months, the accessions from clonal cleaning underwent agronomic characterization by means of the following analysis: plant height, in $\mathrm{m}$; shoot weight, $\mathrm{kg} \mathrm{pl}^{-1}$; number of roots per plant; root weight per plant, $\mathrm{kg}^{-1} \mathrm{pl}$; root length, $\mathrm{cm} \mathrm{pl}^{-1}$; root diameter, $\mathrm{cm} \mathrm{pl}^{-1}$; dry matter content (measured by hydrostatic balance, according to Kawano et al. (1978), in \%; and starch production (considering root weight and dry weight), $\mathrm{g} \mathrm{pl}^{-1}$. The root length and root diameter traits were measured in three roots of each plant.

\section{Data analysis}

The data collected from the agronomic evaluation of plants in the treatments were subjected to $\mathrm{F}$ tests. The treatment means were compared 
using the $\mathrm{F}$ and Tukey tests at 5\% probability. Since the goal was to identify the best concentration of tetracycline and not to analyze the concentration range, polynomial regression models were not used.

The number of roots variable was transformed to $\sqrt{x}$ to meet the assumptions of variance analysis. All of the statistical analyses were performed using Statistical Analysis System (SAS) statistical software (SAS INSTITUTE, 2004).

\section{RESULTS AND DISCUSSION}

Table 1. Summary of the analysis of variance for plant height (PlHe), in $\mathrm{m}$; shoot weight ( $\mathrm{ShWe}), \mathrm{kg} \mathrm{pl}^{-1}$; number of roots per plant (NuRo); root weight (RoWe), $\mathrm{kg} \mathrm{pl}^{-1}$; root length (RoLe), $\mathrm{cm} \mathrm{pl}^{-1}$; root diameter (RoDi), $\mathrm{cm} \mathrm{pl}^{-1}$; dry matter content (DMC) in \%, and starch production (StPr), $\mathrm{g} \mathrm{p}^{-1}$, from shoot tip plants cultivated in vitro at different tetracycline concentrations.

\begin{tabular}{|c|c|c|c|c|c|c|c|c|c|}
\hline \multirow{2}{*}{ Sources of variation } & \multirow{2}{*}{$\begin{array}{l}\text { Degree } \\
\text { of } \\
\text { freedom }\end{array}$} & \multicolumn{8}{|c|}{ Mean square } \\
\hline & & $\mathrm{PlHe}$ & ShWe & NuRo & RoWe & RoLe & RoDi & $\mathrm{DMC}$ & StPr \\
\hline Accession (AC) & 2 & $4.74 * *$ & $10.14 * *$ & $7.26 * *$ & $9.52 *$ & $537.11 * *$ & $7.28 * *$ & $69.59 * *$ & $608009.63 * *$ \\
\hline Shoot tip size (STS) & 1 & $0.07^{\mathrm{ns}}$ & $1.19^{\mathrm{ns}}$ & $0.12^{\mathrm{ns}}$ & $0.01^{\mathrm{ns}}$ & $0.76^{\mathrm{ns}}$ & $0.60^{\mathrm{ns}}$ & $21.02^{\mathrm{ns}}$ & $2387.54^{\mathrm{ns}}$ \\
\hline $\begin{array}{l}\text { Tetracyclin } \\
\text { Concentration (TC) }\end{array}$ & 3 & $0.19^{\mathrm{ns}}$ & $4.31^{* *}$ & $0.28^{\mathrm{ns}}$ & $0.63^{\mathrm{ns}}$ & $20.15^{\mathrm{ns}}$ & $1.87 * *$ & $15.42^{\mathrm{ns}}$ & $55446.01^{\mathrm{ns}}$ \\
\hline AC x STS & 2 & $0.01^{\mathrm{ns}}$ & $0.38^{\mathrm{ns}}$ & $0.12^{\mathrm{ns}}$ & $0.10^{\mathrm{ns}}$ & $13.97^{\mathrm{ns}}$ & $0.47^{\mathrm{ns}}$ & $2.56^{\mathrm{ns}}$ & $4573.02^{\mathrm{ns}}$ \\
\hline $\mathrm{AC} \times \mathrm{TC}$ & 6 & $0.06^{\mathrm{ns}}$ & $2.36 * *$ & $0.21^{\mathrm{ns}}$ & $0.53^{\mathrm{ns}}$ & $12.52^{\mathrm{ns}}$ & $0.43^{\mathrm{ns}}$ & $8.65^{\mathrm{ns}}$ & $44788.05^{\mathrm{ns}}$ \\
\hline STS $x$ TC & 3 & $0.06^{\mathrm{ns}}$ & $0.22^{\mathrm{ns}}$ & $0.98 *$ & $0.43^{\text {ns }}$ & $3.56^{\mathrm{ns}}$ & $0.84^{\text {ns }}$ & $1.91^{\mathrm{ns}}$ & $45641.27^{\mathrm{ns}}$ \\
\hline AC $x$ STS $x$ TC & 6 & $0.12^{\mathrm{ns}}$ & $0.92^{\mathrm{ns}}$ & $0.26^{\mathrm{ns}}$ & $0.19^{\mathrm{ns}}$ & $13.26^{\mathrm{ns}}$ & $0.19^{\mathrm{ns}}$ & $33.42 *$ & $20231.93^{\mathrm{ns}}$ \\
\hline Error & 185 & 0.10 & 0.70 & 0.26 & 0.44 & 30.59 & 0.54 & 14.43 & 42897.86 \\
\hline $\begin{array}{l}\text { Coefficient of } \\
\text { variation }(\%)\end{array}$ & & 14.01 & 40.12 & 18.49 & 43.66 & 29.20 & 16.53 & 11.04 & 45.24 \\
\hline General Average & & 2.29 & 2.09 & 7.84 & 1.53 & 18.94 & 4.44 & 34.41 & 457.77 \\
\hline
\end{tabular}

$\mathrm{ns},{ }^{* *}, *$ : not significant, and significant at $1 \%$ and $5 \%$ by $\mathrm{F}$ test, respectively.

In most of the treatments, the agronomic attributes evaluated were not affected by the shoot tip size that gave origin or by the tetracycline concentration used. In addition, in Figures 1 to 4, regardless the analyzed characteristic, the highest average in agronomic evaluation was found in accession BGM0464, although BGM0841 displayed superior behavior in root diameter (Figure 3), and BGM0315 produced high dry matter content (Figure 4).

For plant height, the means ranged from 2.03 and $2.54 \mathrm{~m}$ in the accessions BGM0841 and BGM0464, respectively (Figure 1). This trait is very important in this type of assessment, because it indicates the amount of propagation material (cuttings, seeds) available for new plantations. In general, the height observed in cassava plants grown in vitro, after seven months in the field, are very close to those obtained by conventional propagation (cuttings), with harvest taken between 11 and 15 months after planting (FOLONI et al. 2010;
F-test from analysis of variation revealed significant accession effect, but no differences among the shoot tip size for all traits, which indicates contrasts between the cassava accessions response regarding agronomic traits (Table 1). The tetracyclin concentration presented some difference effect only for shoot weight and root diameter. Additionally, some interactions were observed for shoot weight (accession $\mathrm{x}$ tetracyclin concentration), number of roots per plant (shoot tip size $\mathrm{x}$ tetracyclin concentration), and dry matter content (accession $\mathrm{x}$ shoot tip size $\mathrm{x}$ tetracyclin concentration). 


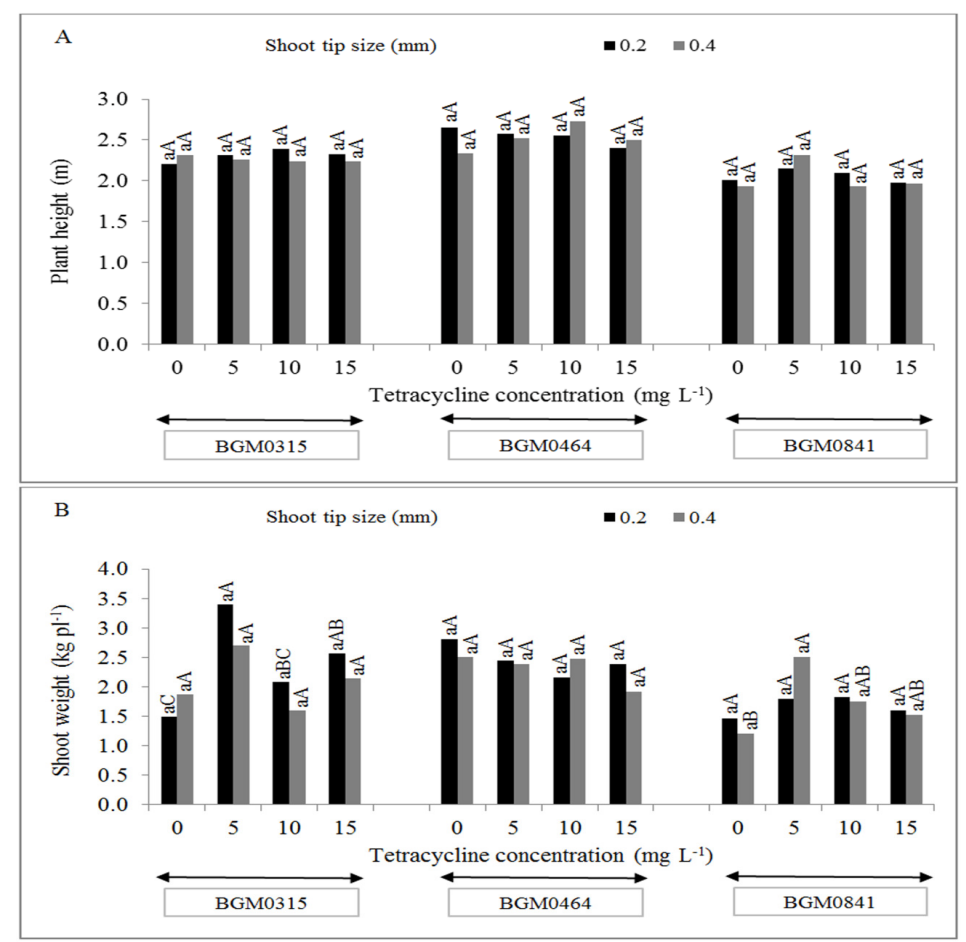

Figure 1. Plant height and shoot weight means from accessions BGM0315, BGM0464 and BGM0841 cultivated in vitro. Means followed by the same uppercase letters (compare different tetracycline concentrations in each apex size in each accession) and lowercase (compare the apex sizes in each tetracycline concentration) do not differ significantly by the $\mathrm{F}$ test $(\mathrm{p} \leq 0.05)$ and Tukey test $(\mathrm{p} \leq 0.05)$, respectively.

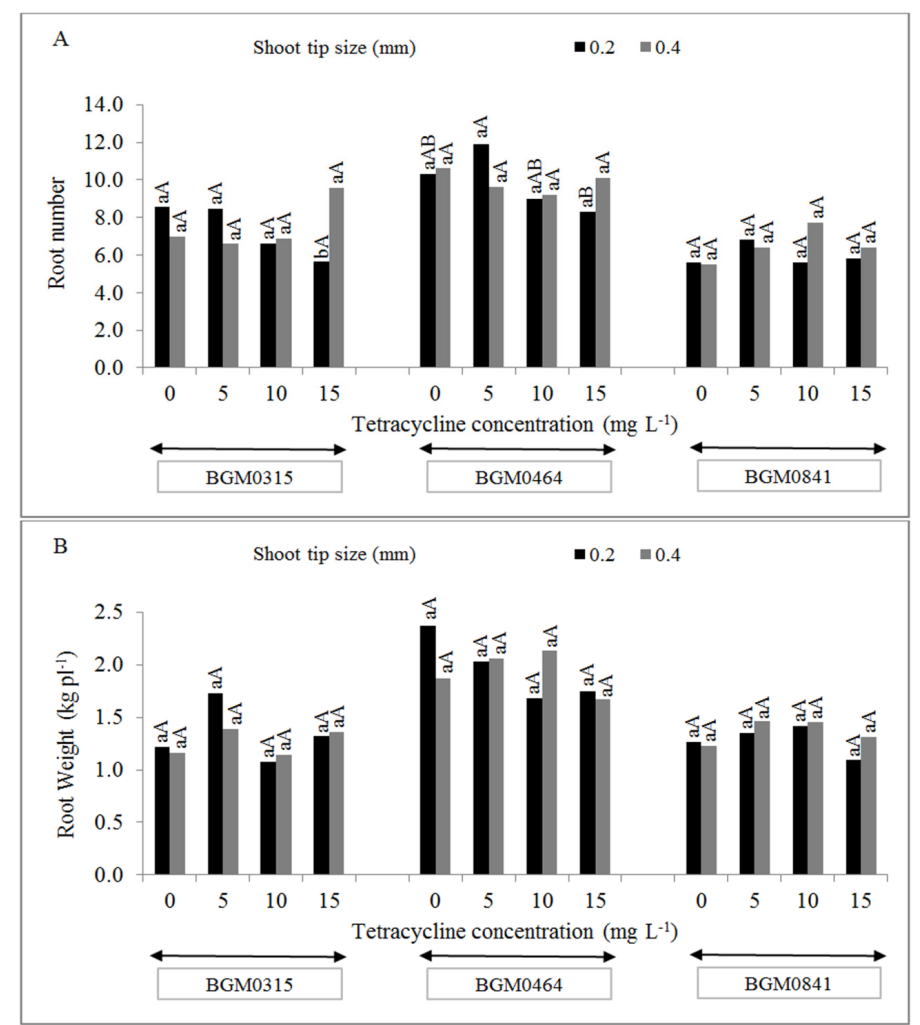

Figure 2. Number of roots and root weight means from accessions BGM0315, BGM0464 and BGM0841 cultivated in vitro. Means followed by the same uppercase letters (compare different tetracycline concentrations in each apex size in each accession) and lowercase (compare the apex sizes in each tetracycline concentration) do not differ significantly by the $\mathrm{F}$ test $(\mathrm{p} \leq 0.05)$ and Tukey test $(\mathrm{p} \leq 0.05)$, respectively. 


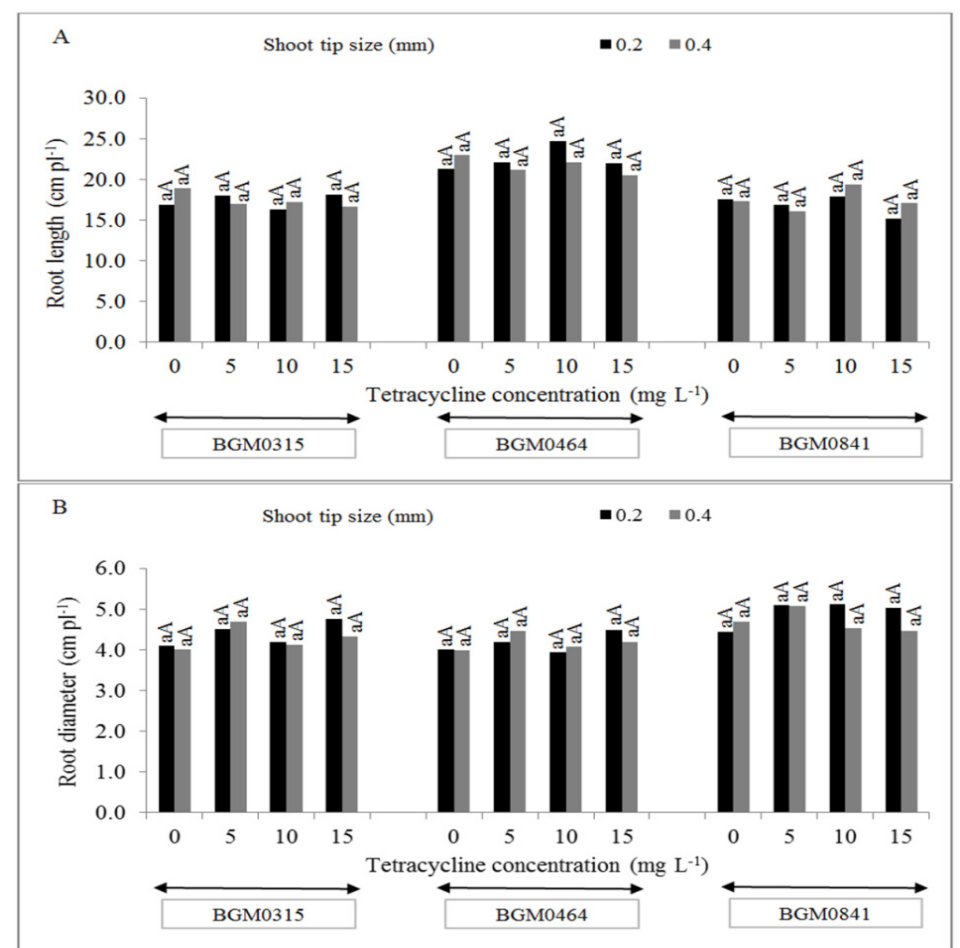

Figure 3. Length and root diameter means from accessions BGM0315, BGM0464 and BGM0841 grown in vitro. Means followed by the same uppercase letters (compare different tetracycline concentrations in each apex size in each accession) and lowercase (compare the apex sizes in each tetracycline concentration) do not differ significantly by the $F$ test $(p \leq 0.05)$ and Tukey test $(p \leq 0.05)$, respectively.

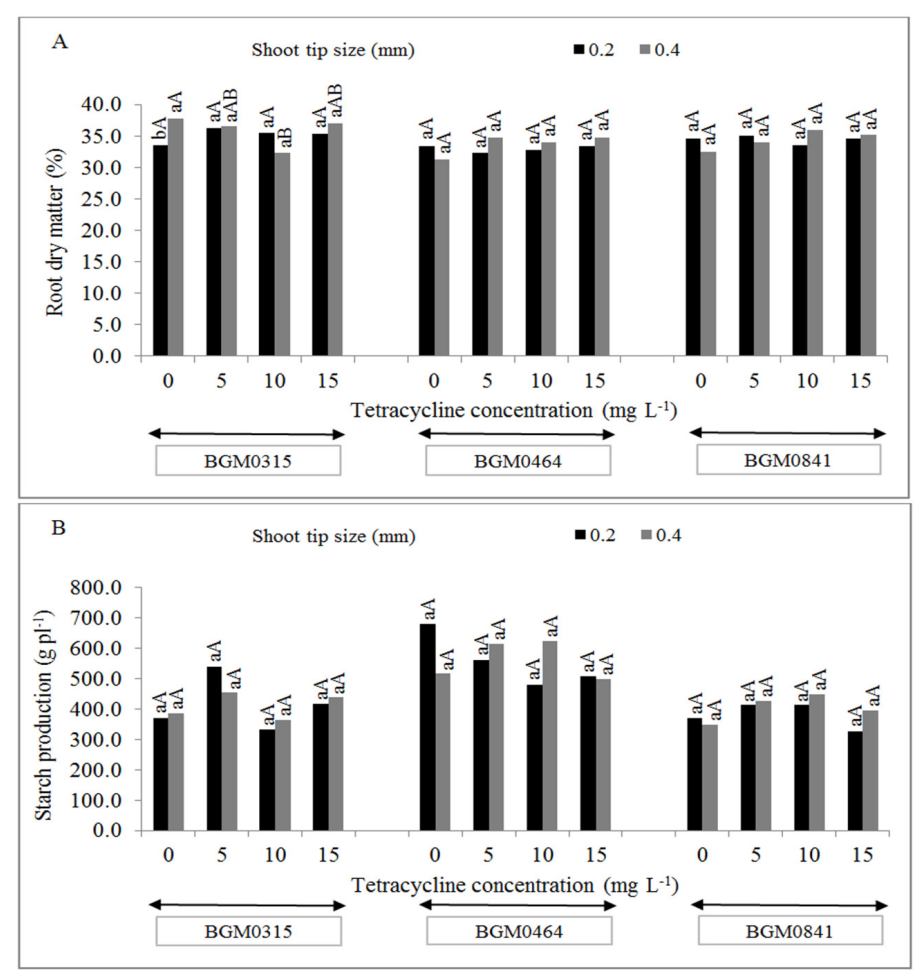

Figure 4. Dry matter content and starch production means from accessions BGM0315, BGM0464 and BGM0841 accessions cultivated in vitro. Means followed by the same uppercase letters (compare different tetracycline concentrations in each apex size in each accession) and lowercase (compare the apex sizes in each tetracycline concentration) do not differ significantly by the $F$ test $(p \leq 0.05)$ and Tukey test $(\mathrm{p} \leq 0.05)$, respectively. 
There were no differences among plants for shoot weight based on shoot tip sizes during clonal cleaning of accessions BGM0464 and BGM0841. Although the plants with $0.4 \mathrm{~mm}$ apexes from BGM0841, presented a slight reduction of shoot weight when grown in the absence of tetracycline. In contrast, when grown in the field, plants from BGM0315 showed higher shoot weight when their shoot tips were grown in tetracycline concentrations of 5 and $15 \mathrm{mg} \mathrm{L}^{-1}$ (Figure 1). This nonlinear stimulation of shoot weight relative to the antibiotic dose of only accession BGM0315 may be due to some random effect of the crop in the field. Other hypotheses to explain this behavior refers to the fact that BGM0315 cultivated in vitro is free of endogenous microorganisms, resulting in increased plant vigor, besides the fact that tetracycline antibiotic in the in vitro culture phase acts as a growth regulator and thus generates stimulus for shoot growth in some genotypes. Indeed, the activity of some antibiotics as growth regulators has been reported in the literature. According to Mathias and Mukasa (1987) the callus grown in the presence of cefotaxime showed development up to $45 \%$ higher than the control; furthermore, the callus regeneration rate increased by $80 \%$, evidencing that the antibiotic promoted growth and morphogenesis in barley callus.

On average, shoot weight ranged from 2.25 , 2.37 and $1.67 \mathrm{~kg} \mathrm{pl}^{-1}$ in accessions BGM0315, BGM0464 and BGM0841, respectively. Reports of shoot weight ranging from 0.60 to $1.88 \mathrm{~kg}$ per plant (PERESSIN; MONTEIRO, 1998; GOMES et al., 2007, SILVA et al., 2009) show that the above cassava accessions grown in vitro and evaluated at seven months in field conditions showed high vegetative vigor in serving as a basic planting material for the following production cycles. These differences in the shoot weight may be related to the specific characteristics of the accession, the different soil and climatic conditions of the experimental installation locations and the fact the plants from the clonal cleaning by in vitro culture are free of endogenous microorganisms, resulting in a higher shoot weight, which can also be associated with activity of the antibiotic tetracycline as a growth regulator, as mentioned above.

The averages observed for root weight per plant were $1.30,1.31$ and $1.94 \mathrm{~kg} \mathrm{p}^{-1}$ in the accessions BGM0315, BGM0841 and BGM0464, respectively (Figure 2). Even with early harvest (seven months), the average values of root weight per plant were much higher than those observed in the work of Peressin and Monteiro (1998) (root weight per plant $=0.65 \mathrm{~kg}$ ) and Gomes et al. (2007) (root weight per plant $=1.09 \mathrm{~kg}$ ), who used cuttings of other genotypes that were harvested at seven and 11 months after planting, respectively.

On the other hand, Oliveira and Moraes (2009) reported an average root weight per plant of $3.30 \mathrm{~kg}$ per plant in plants harvested seven months after planting when they used IAC 576-70. However, it is important to note that the average root weight per plant of $1.53 \mathrm{~kg} \mathrm{pl}^{-1}$ observed in this study was obtained when evaluating unimproved cassava accessions among plants from in vitro culture. Even under these conditions, and considering the planting spacing of $0.90 \times 0.80 \mathrm{~m}$, the potential of root weight per plant ranging from 18.06 to $26.94 \mathrm{t} \mathrm{ha}^{-1}$ in the accessions BGM0315 and BGM0464, respectively, which is well above the national average productivity of around $15.23 \mathrm{t}$ $\mathrm{ha}^{-1}$ (IBGE, 2015).

Lozano et al. (1984) also reported that the Secundina variety, originated from tissue culture and harvested at 12 months, showed higher fresh root yield (range 24.0 to $26.0 \mathrm{t} \mathrm{ha}^{-1}$ ) than plants of the same variety propagated by cuttings $\left(19.6 \mathrm{t} \mathrm{ha}^{-1}\right)$. Therefore, the results indicate and consolidate previous information on achieving fresh root productivity comparable to conventional crops coming from cuttings in the first cycle of in vitro propagation.

For number of roots per plant, there were no differences between plants from the accessions BGM0315 and BGM0464 due to the shoot tip size that originated when the explants were cultivated at a tetracycline concentration of $15 \mathrm{mg} \mathrm{L}^{-1}$, with greater number of roots per plant observed from shoot tips of $0.4 \mathrm{~mm}$ (Figure 2). This result can be explained by the arguments mentioned above for shoot weight regarding an increased expression of genetic potential in pathogen-free plants after clonal cleaning as well as the role of antibiotics as a growth regulator and in plant development. The number of roots per plant ranged from 6.23 to 9.85 in the accessions BGM0841 and BGM0464, respectively, averaging 7.84 roots per plant (Figure 2). Comparative analysis of cassava plants propagated conventionally shows that the variation from 4.12 to 7.50 roots per plant (BARBOSA et al., 2007; GOMES et al., 2007; SILVA et al., 2009) is within the observations for plants originating from clonal cleaning (during in vitro culture).

Specifically regarding root characteristics, root length ranged from 17.2 to $22.7 \mathrm{~cm}$ in the accessions BGM0841 and BGM0464, respectively, averaging $18.9 \mathrm{~cm}$, while the root diameter (RoDi) ranged from 4.2 to $4.8 \mathrm{~cm}$ in the BGM0464 and BGM0841, respectively, with a general average of 
$4.4 \mathrm{~cm}$ (Figure 3). Regardless the accessions used, the highest averages for root diameter were obtained in the presence of tetracycline, especially in concentrations of 5 and $15 \mathrm{mg} \mathrm{L}^{-1}$, showing the effect of this antibiotic on root diameter expression in field conditions (Figure 3).

When evaluating the performance of two cassava cultivars under field conditions (Thaill and 193/017) derived from tissue culture at 8 months of harvest, Msogoya and Viljoen (2006) observed fast growth with higher root weight per plant (range from 13. 0 to $26.0 \mathrm{t} \mathrm{ha}^{-1}$ ) and root length (range from 34.2 to $38.2 \mathrm{~cm})$ in plants from tissue culture, compared to those from the conventional cultivation (root weight per plant ranging from 9.0 to $21.0 \mathrm{t} \mathrm{ha}^{1}$ and root length ranging from 25 to $30 \mathrm{~cm}$ ). Although root weight per plant and root length are highly affected by the variety used, as per soil conditions and culture environment, these comparisons all show that plants from in vitro cultivation present agronomic crops that not only can be used as propagation material for the next planting cycle but also as an income source through the possible commercial exploitation of the roots generated by these plants.

For the dry matter content in the roots, there was no difference among cassava accessions in terms of antibiotic concentrations as a function of the shoot tip sizes from which they originated, except for the BGM0315 which presented the highest dry matter content in plants originating from $0.4 \mathrm{~mm}$ shoot tips cultivated in the absence and presence of 5 and $15 \mathrm{mg} \mathrm{L}^{-1}$ (Figure 4). The dry matter content averages ranged from 31.20 to $37.76 \%$ in the accessions BGM0464 and BGM0315, respectively. On the other hand, Oliveira et al. (2015) reported dry matter content of up to 44\% in the roots of different Brazilian cassava accessions.

The dry matter content of the roots is influenced by genetic origin as well as climatic and soil conditions, such as the variation in dry matter content of $30-38 \%$, with an overall average of $35 \%$ reported by Carvalho et al. (2014), who evaluated different cassava cultivars. Their results among plants from conventional propagation were similar to those found in this study (overall average of $34.41 \%$ ). Moreover, Msogoya and Viljoen (2006) found a higher dry matter yield in the roots of plants from in vitro culture (4.0 to $9.0 \mathrm{t} \mathrm{ha}^{-1}$ ) than those from conventional propagation (3.0 to $7.5 \mathrm{t} \mathrm{ha}^{-1}$ ).

For the variable starch production, the averages ranged between 392.18 and $562.21 \mathrm{~g} \mathrm{pl}^{-1}$, respectively, for the accessions BGM0841 and BGM0464 (Figure 4). These results showed similar behavior between root weight per plant and starch production traits on BGM0464, which stood out in most agronomic characteristics in relation to the other accessions (BGM0315 and BGM841). In general, starch production and root weight per plant had a high positive correlation (0.98**), indicating that the plants with higher root weight per plant achieved that higher starch production. Starch production is a characteristic of great importance to the flour and starch industry because the root price is set according to this characteristic. Accordingly, the starch yield must be taken into consideration when choosing the selection to be used in a largescale production system (OLIVEIRA et al., 2015). Therefore, it has also became evident for dry matter content and starch production that plants from in vitro culture are competitive for direct use of roots in the flour and starch industries, which value varieties with high yield for these attributes.

It is worth noting that during harvesting, visual root analysis of the plants from all treatments showed, in addition to good agronomic performance, the efficiency of cassava frogskin disease removal in infected plants after the use of the tissue culture technique associated with thermotherapy and chemotherapy, which for most treatments was $100 \%$ among asymptomatic plants after seven months of culture (data not shown). Moreover, among cassava frogskin disease -infected accessions, BGM0315 and BGM0464 were also infected with cassava vein mosaic virus. In a total of 143 plants analyzed after clonal cleaning, only three plants tested positive based on polymerase chain reaction. Therefore, the protocol used, besides being effective in eliminating cassava frogskin disease and cassava vein mosaic virus, did not negatively affect the agronomic performance of the plants in the field.

Even with the harvest of accessions BGM0315, BGM0464 and BGM0841 in quite an early form (seven months after planting), a great development of shoots and roots in all accessions were observed. According to Msogoya and Viljoen (2006), this may be associated with the increased performance of cassava plants from tissue culture by presenting accelerated initial establishment. Similar observations were noticed in other species of clonal propagation, such as banana (CHAVAN-PATIL et al., 2010), sugarcane (SANDHU et al., 2009), sweet potato (OZTURK et al., 2012.) and strawberry (ŻEBROWSKA et al., 2015; DIENGNGAN et al., 2016), with similar or superior results in many agronomic characteristics to those seen in conventionally cultivated plants. Despite the very positive results, because of the dual purpose of cassava cuttings from in vitro cultivation (production of healthy cuttings for commercial 
planting and income generation with the roots generated by these plants), it is necessary to evaluate a greater number of accessions and varieties to confirm this potential.

\section{CONCLUSIONS}

The field production of cassava propagation material derived from in vitro cultivation have the potential to generate income from the sale of the roots because of their high production potential, specifically when the accessions are cultivated in culture medium at concentrations of 5 and $15 \mathrm{mg} \mathrm{L}^{-1}$ of tetracycline, due to the better roots development.

\section{ACKNOWLEDGEMENTS}

The authors thank CNPq, Fapesb and CAPES for the funding and support necessary for this research.

RESUMO: Este trabalho teve por objetivo avaliar o desempenho agronômico de genótipos de mandioca provenientes do cultivo in vitro de ápices caulinares para eliminação da doença couro de sapo (Cassava frogskin disease, CFSD), em relação a diversas características de raiz e da parte aérea. Para isso, foram utilizadas plantas de mandioca dos acessos BGM0315, BGM0464 e BGM0841 cultivadas em casa de vegetação após a limpeza clonal. Inicialmente, foram utilizadas manivas de plantas adultas infectadas com couro de sapo. Essas manivas foram submetidas a concentrações de tetraciclina $\left(0,5,10 \mathrm{e} 15 \mathrm{mg} \mathrm{L}^{-1}\right)$ por 3 minutos. Posteriormente, foram mantidas em câmara climatizada $\left(35 \pm 1^{\circ} \mathrm{C}\right.$ e fotoperíodo de 16 horas). Brotos foram desinfestados para excisão de ápices caulinares $(0,2 \mathrm{~mm}$ e $0,4 \mathrm{~mm})$ e inoculados em meio de cultura contendo as mesmas concentrações de tetraciclina empregadas nas manivas. Aos 60 dias de cultivo, os explantes foram transferidos para meio sem antibiótico, 30 dias após foram aclimatizadas por um período de 70 dias para posterior plantio em campo. Aos sete meses após o plantio realizou-se a avaliação agronômica para características de raiz e parte aérea. Não houve influência do tamanho do ápice caulinar isoladamente nas características agronômicas avaliadas, enquanto que a adição de tetraciclina no meio de cultura, especificamente nas concentrações de 5 e $15 \mathrm{mg} \mathrm{L}^{-1}$, foi favorável ao desenvolvimento do sistema radicular das plantas no campo. Os resultados evidenciaram que o desempenho agronômico de plantas de mandioca provenientes do cultivo in vitro são elevados para produção de material propagativo básico para os ciclos seguintes de produção, bem como para produção de raízes para uso comercial com consequente geração de renda.

PALAVRAS-CHAVE: Manihot esculenta Crantz. Cultura de tecidos. Qualidade fitossanitária. Produtividade de raízes.

\section{REFERENCES}

ALAM, I.; SHARMIN, S. A.; NAHER, K.; ALAM, J.; ANISUZZAMAN, M.; ALAM, M. F. Elimination and detection of viruses in meristem-derived plantlets of sweetpotato as a low-cost option toward commercialization. Journal of Biotechnology, Bielefeld, v. 3, n. 2, p. 153-164, 2013. http://dx.doi.org/10.1007/s13205-012-0080-6.

ALVAREZ, E.; MEJIA, J. F.; LLANO, G. A.; LOKE, J. B. Detection and characterization of a phytoplasma associated with frog skin disease in cassava. Bulletin of Insectology, Bologna, v. 60, p. 273-274, 2007.

ALVAREZ, E.; MEJÍA, J. F.; LLANO, G.; LOKE, J.; CALARI, A.; DUDUK, B.; BERTACCINI, A. Characterization of a phytoplasma associated with frogskin disease in cassava. Plant Disease, Cambridge, v. 93, p. 1139-1145, 2009.

ALVAREZ, E.; PARDO, J. M.; ZACHER, M.; CARDOZO, L.; TORRES, A. "Cuero de Sapo": enfermedad de la mandioca en Paraguay. Cali: CIAT, 2014. 1 p.

BANERJEE, S.; HAIDER F.; BAGCHI, G. D.; SAMAD, A. Regeneration of phytoplasma-free Artemisia roxburghiana Besser var. purpurascens (Jacq.) Hook. plants using apical meristem culture. Plant Cell, Tissue and Organ Culture, Amsterdam, v. 103, p. 189-196, 2010. http://dx.doi.org/ 10.1007/s11240-010-9766-9. 
BARBOSA, C. Z. dos R.; ALVES, J. M. A.; SCHWENGBER, D. R.; SMIDERLE, O. J. Características morfológicas e agronômicas de dez clones de mandioca cultivados no Estado de Roraima. Revista Agro@mbiente On-line, Boa Vista, v.1, n. 1, p.28-31, 2007.

BRAVATO, M.; ZAPATA, C.; COLL, H. Field evaluation of in vitro plants of cassava (Manihot esculenta Crantz) for several generations. In: ROCA, W.M.; THRO, A.M. (Ed.). INTERNATIONAL SCIENTIFIC MEETING OF THE CASSAVA BIOTECHNOLOGY NETWORK, 1., 1992, Cartagena. Proceedings... Cali: CIAT, 1993. p.105-110. (CIAT. Working Document, 123).

CALVERT, L. A.; THRESH, J. M. Virus and virus diseases of cassava. In: HILLOCKS, R. J.; THRESH, J. M.; BELLOTI, A. (Ed.). Cassava: biology, production and utilization. Wallingford: CABI Publishing, 2002. p. 237-260.

CARVAJAL-YEPES, M.; OLAYA, C.; LOZANO, I.; CUERVO, M.; CASTAÑO, M.; CUELLAR, W. J. Unraveling complex viral infections in cassava (Manihot esculenta Crantz) from Colombia. Virus Research, Amsterdam, v. 186, p. 76-86, 2014. http://dx.doi.org/10.1016/j.virusres.2013.12.011.

CARVALHO, H. W. L. de; RANGEL, M. A. S.; SANTOS, V. da S.; OLIVEIRA, I. R. de; PINHO, J. L. N. de; ALVES, M. C. S.; SILVA, A. D. A. da; OLIVEIRA, T. R. A. de; RODRIGUES, C. S.; CASTRO, C. R.; MARQUES, M. G.; MENEZES, V. M. M.; SANTOS, D. L. dos; MOITINHO, A. C.; SANTOS, M. L. dos. Avaliação de cultivares de mandioca em ambientes de Tabuleiros e Agreste inseridos nos Estados da Bahia e Sergipe: safra 2010/2011. Aracaju: Embrapa Tabuleiros Costeiros, 2014. 29 p. (Embrapa Tabuleiros Costeiros. Boletim de Pesquisa e Desenvolvimento, 85).

CHAVAN-PATIL, V. B.; AREKAR, C. D.; GAIKWAD, D. K. Field performance of in vitro propagated banana plants from $8^{\text {th }}$ and $15^{\text {th }}$ subculture. International Journal of Advanced Biotechnology and Research, Rapid City, v. 1, n. 2, p. 96-103, 2010.

DIENGNGAN, S.; MAHADEVAMMA, M.; MURTHY, B. N. S. Efficacy of in vitro propagation and crown sizes on the performance of strawberry (Fragariaxananassa Duch) cv. Festival under field condition. Journal of Agricultural Science and Technology, Tehran, v. 18, n. 1, p. 255-264, 2016.

FAYEK, M. A.; JOMAA, A. H.; SHALABY, A. A.; AL-DHAHER, M. A. A meristem tip culture for in vitro eradication of grapevine leaf roll associated virus-1(GLRaV-1) and grapevine fan leaf virus (GFLV) from infected flame seedless grapevine plantlets. Iniciación a la Investigación, Jaén, v. 4, p. 1-11, 2009.

FAO. Food and agriculture organization of the united nations statistics division, 2014. Disponível em: <http://faostat3.fao.org/browse/Q/QC/E, 2014>. Acesso em: 01 mar. 2016.

FOLONI, J. S. S.; TIRITAN, C. S.; SANTOS, D. H. Avaliação de cultivares de mandioca na Região Oeste do Estado de São Paulo. Revista Agrarian, Dourados, v. 3, n. 7, p. 44-50, 2010.

GOMES, C. N.; CARVALHO, S. P.; JESUS, A. M. S.; CUSTÓDIO, T. N. Caracterização morfoagronômica e coeficientes de trilha de caracteres componentes da produção em mandioca. Pesquisa Agropecuária Brasileira, Brasília, DF, v. 42, n. 8, p. 1121-1130, 2007. http://dx.doi.org/ 10.1590/S0100204X2007000800008.

IBGE. Levantamento Sistemático da produção Agrícola: pesquisa mensal de previsão e acompanhamento das safras agrícolas no ano civil. Rio de Janeiro: IBGE, 2015. v. 29, n. 12, p. 1-88. Disponível em: $<$ http://ftp.ibge.gov.br/Producao_Agricola/Levantamento_Sistematico_da_Producao_Agricola_\%5Bmensal\%5 D/Fasciculo/2015/lspa_201512.pdf>. Acesso em: 27 jun. 2016.

KAWANO, K.; DAZA, P.; AMAYA, A.; RÍOS, M.; GONÇALVEZ, M.F. Evaluation of cassava germplasm for productivity. Crop Science, Madison, v. 18, p. 377-380, 1978. http://dx.doi.org/10.2135/cropsci1978.0011183X001800030006x. 
KVITSCHAL, M. V.; VIDIGAL FILHO, P. S.; PEQUENO, M. G.; SAGRILO, E.; BRUMETTI, C. C.; MANZOTTI, M.; BEVILAQUA, G. Avaliação de clones de mandioca (Manihot esculenta Crantz) para indústria na região noroeste do Paraná. Acta Scientiarum: Agronomy, Maringá, v. 25, n. 2, p. 299-304, 2003. http://dx.doi.org/10.4025/actasciagron.v25i2.1784.

LOZANO, J. C.; PINEDA, B.; JAYASINGHE, U. Effect of cutting quality on cassava. In: SYMPOSIUM OF THE INTERNATIONAL SOCIETY FOR TROPICAL ROOT CROPS, 6., 1983, Lima. Proceedings... Lima: International Potato Center, 1984. p. 433-439.

MATHIAS, R. J.; MUKASA, C. The effect of cefotaxime on the growth and regeneration of callus from four varieties of barley (Hordeum vulgare L.). Plant Cell Reports, Berlin/Heidelberg, v. 6, p. 454-457, 1987. http://dx.doi.org/ 10.1007/BF00272781.

MATTOS, P. L. P. de; GOMES, J. de C.; FARIAS, A. R. N.; FUKUDA, C. Cultivo da mandioca nas regiões norte e nordeste do Brasil. In: CEREDA, M. P. (Ed.). Agricultura: tuberosas amiláceas Latino Americanas. São Paulo: Cargill, 2002. v. 2, p. 274-301.

MSOGOYA, T. J.; VILJOEN, J. Field performance of cassava (Manihot esculenta Crantz) established from tissue culture-derived plantlets and conventional stem cuttings. Tanzania Journal of Agricultural Sciences, Grahamstown, v. 7, n. 2, p. 111-116, 2006.

MURASHIGE, T.; SKOOG, F. A revised medium for rapid growth and bioassays with tobacco tissue culture. Physiologia Plantarum, Copenhagen, v. 15, n. 3, p. 473-497, 1962. http://dx.doi.org/10.1111/j.13993054.1962.tb08052.

MWANGANGI, M.; ATEKA, E.; NYENDE, A.; KAGUNDU, A. Elimination of cassava brown streak virus from infected cassava. Journal of Biology, Agriculture and Healthcare, New York, v. 4, n. 13, p. 34-40, 2014.

NEHRA, N. S.; KARTHA, K. K.; STUSHNOFF, C.; GILES, K. L. Effect of in vitro propagation methods on field performance of two strawberry cultivars. Euphytica, Dordrecht, v. 76, p. 107-115, 1994.

http://dx.doi.org/10.1007/BF00024027.

OLIVEIRA, E. J; SANTANA, F. A.; OLIVEIRA, L. A.; SANTOS, V. S. Genetic parameters and prediction of genotypic values for root quality traits in cassava using REML/BLUP. Genetics and Molecular Research, Ribeirão Preto, v. 13, n 3, p. 6683-6700, 2014. http://dx.doi.org/ 10.4238/2014.August.28.13.

OLIVEIRA, M. A.; MORAES, P. S. B. Características físico-químicas, cozimento e produtividade de mandioca cultivar IAC 576-70 em diferentes épocas de colheita. Ciência e Agrotecnologia, Lavras, v. 33 n. 3 , p. 837-843, 2009. http://dx.doi.org/ 10.1590/S1413-70542009000300024.

OZTURK, G.; AZERI, F. N.; YILDIRIM, Z. Field performance of in vitro sweet potato [Ipomoea batatas L.(Lam)] plantlets derived from seedstocks. Turkish Journal of Field Crops, Konak-Izmir, v. 17, n. 1, p. 1-4, 2012.

PASSOS, A. M. A. dos; FERRO, G. O. ; PAULA, N. M. G. e. ; SILVA JUNIOR, J. S. Desempenho de genótipos de mandioca em um argissolo eutrófico na região Sudoeste da Amazônia. Enciclopédia Biosfera, Goiânia, v. 10, n. 19; p. 721- 731, 2014.

PERESSIN A. A.; MONTEIRO, D. A. Acúmulo de matéria seca na presença e na ausência de plantas infestantes no cultivar de mandioca SRT 59 - Branca de Santa Catarina. Bragantia, Campinas v. 57, n. 1, p. 135-148, 1998. http://dx.doi.org/10.1590/S0006-87051998000100016. 
SANDHU, S. K.; GOSAL, S. S.; THIND, K. S.; UPPAL, S. K.; SHARMA, B.; MEETA, M.; SINGH, K.; CHEEMA, G. S. Field performance of micropropagated plants and potential of seed cane for stalk yield and quality in sugarcane. Sugar Tech, New York, v. 11, n. 1, p. 34-38, 2009. http://dx.doi.org/10.1007/s12355009-0006-8.

SAS INSTITUTE. SAS user's guide: statistic: version 9.1.3. Cary: SAS Institute, 2004. 846 p.

SILVA, A. F.; SANTANA, L. M. de; FRANÇA, C. R. R. S.; MAGALHÃES, C. A. de S.; ARAÚJO, C. R. de; AZEVEDO, S. G. de. Produção de diferentes variedades de mandioca em sistema agroecológico. Revista Brasileira de Engenharia Agrícola e Ambiental, Campinha Grande, v. 13, n. 1, p. 33-38, 2009. http://dx.doi.org/10.1590/S1415-43662009000100005.

SINGH, S. K.; AMINUDDIN, S. P.; SINGH, B. R.; KHAN, J. A. Production of phytoplasma-free plants from yellow leaf diseased Catharanthus roseus L. (G.) Don. Journal of Plant Diseases and Protection, Rostock, v. 114 p. 2-5, 2007. . http://dx.doi.org/10.1007/BF03356195.

ŻEBROWSKA, J.; KACZMARSKA, E.; GAWROŃSKI, J. Comparative studies on the agronomic value of in vitro and conventionally propagated strawberry (Fragaria x ananassa Duch.) plants. Acta Scientiarum

Polonorum Hortorum Cultus, Lublin, v. 14, n. 3, p. 25-35, 2015. 